\title{
Design an Ozone Generator by Using Dielectric Barrier Discharge
}

\author{
Hamid H. Al-Jobouri and Hadeel O. Ismaeel \\ Department of Physics, College of Science for Women, Baghdad University, Baghdad-Iraq.
}

\begin{abstract}
An Ozone generator was designed according to dielectric barrier discharge (DBD) technique with Oxygen as a feed gas for Ozone generating. The effect of the flow rate on the concentration of the Ozone was studied, the flow rate was varied from 0.6 to 5 lit/ $\mathrm{min}$ for two values of the gap space between electrodes $\mathrm{d}=2$ and $4 \mathrm{~mm}$, and two values of the electrode area $\mathrm{A}=20$ and $36 \mathrm{~cm}^{2}$. Also, the effect of the applied voltage on the concentration of the Ozone was studied, the applied voltage was varied from $(1-9 \mathrm{kV})$ for the same gap space and electrode area values. It is found that the concentration of Ozone produced increases with increasing voltage, and decreases with increasing flow rate.
\end{abstract}

Keywords: ozone, Dielectric Barrier Discharge DBD, oxygen, non-Thermal plasma.

\section{Introduction}

Ozone $\left(\mathrm{O}_{3}\right)$ is a strong oxidizing agent and disinfectant that can be applied in various fields such as water treatment, food industries, medicine [1].

Ozone can be produced in three ways: electrical discharge; ultraviolet - rays [2] and electrochemical [3].Sources of Ozone for practical applications are typically used in electrical discharge or always called corona discharge [4] as well as dielectric barrier discharges $[5,6]$.

In dielectric barrier discharge (DBD) plasma with Oxygen or air as sources. One of very important application of Ozone is wastewater control. There have been many efforts for reducing pollution by wastewater, for example by the use of Chlorine, the use of microbiology, activated carbon or membrane filtration. Water pollution degrades the quality of environment and the formation of Oxygen in the water, that used for breathing fish and other aquatic animals. To overcome this problem can be done using non-thermal plasma technologies at atmospheric pressure. Ozone has been used for treating a municipal wastewater plant. The very important reasons for using Ozone water treatment are it can destroy organic compounds and can kill bacteria[7,8]. Ozone is a disinfectant that does not leave the rest of the reaction in the water because the Ozone will decompose back in to Oxygen and also the ability of Ozone to dissolve in water thirteen times more easily than Oxygen and dissolved Ozone in water can be used as standard of water quality $[9,10]$.

\section{Ozone Generation}

The Ozone generator has been built with coaxial electrode geometry configuration, isolated by a barrier layer dielectric (dielectric barrier) from Pyrex glass. The plasma was generated by a high voltage AC from $1 \mathrm{kV}$ to $9 \mathrm{kV}$.

The Ozone cell consists of tube made form Pyrex glass with length of $14 \mathrm{~cm}$ and diameter of $1.2 \mathrm{~cm}$. The cell was connected to the high voltage power supply by two electrodes, the anode was conned through Copper rode with diameter of $1 \mathrm{~cm}$, concentrated inside the tube, and the cathode by sheet of Copper shielded the outside of the tube. The tubes have two opened one to inter the gas and other to exit the Ozone. The gas passes inside the tube through the gap between the anode and the edge of the glass tube as shown in the Fig.(1).

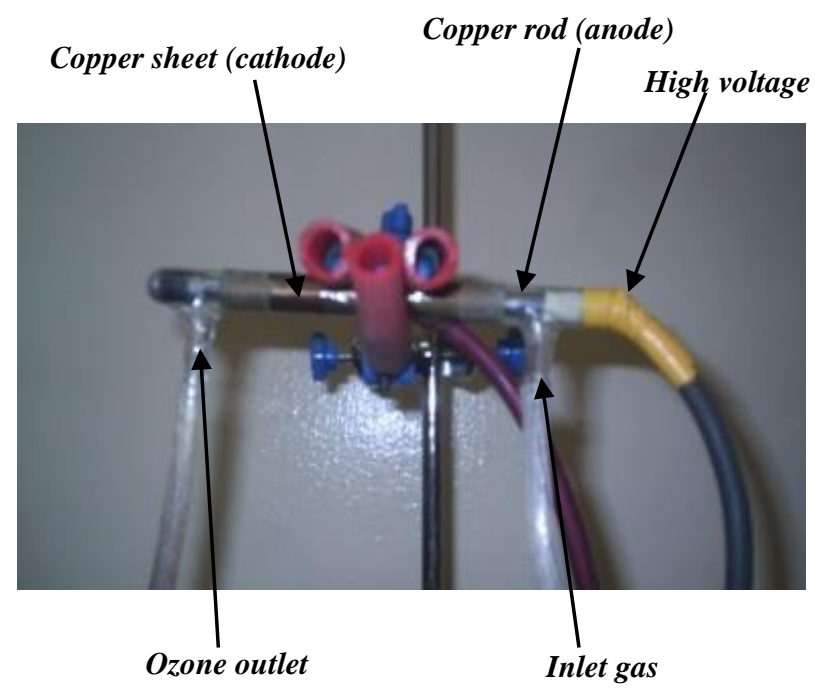

Fig.(1) Scheme of the Ozone cell. 
The gas was fed from the tank or compressor to the flow meter to adjust the flow rate and then inter the Ozone cell. When the high voltage, power supply is swished on, the silent discharge occurs between anode and cathode through the gas, and the Ozone was formed, and exit from the end of the cell

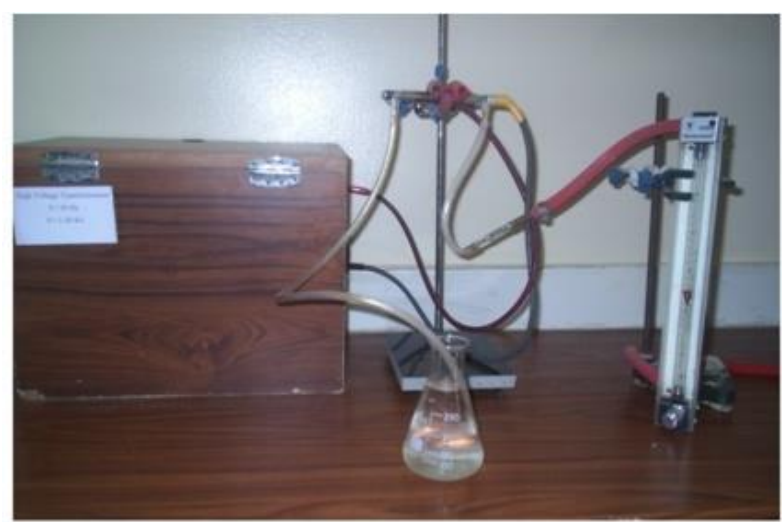

Fig.(2) Ozone generator device with water sample.

\section{Ozone Concentration \\ Effect of flow rate on Ozone concentration}

To study the effect of the flow rate (Q) on the concentration of the Ozone. We measure the concentration of the Ozone for different values of the flow rate $(0.6,1,2,3$, $4,5) \mathrm{lit} / \mathrm{min}$, and electrode area $\left(\mathrm{A}_{\mathrm{e}}=20 \mathrm{~cm}^{2}\right)$ and gap space $(\mathrm{d}=4 \mathrm{~mm})$. The results are shown in Fig.(3).

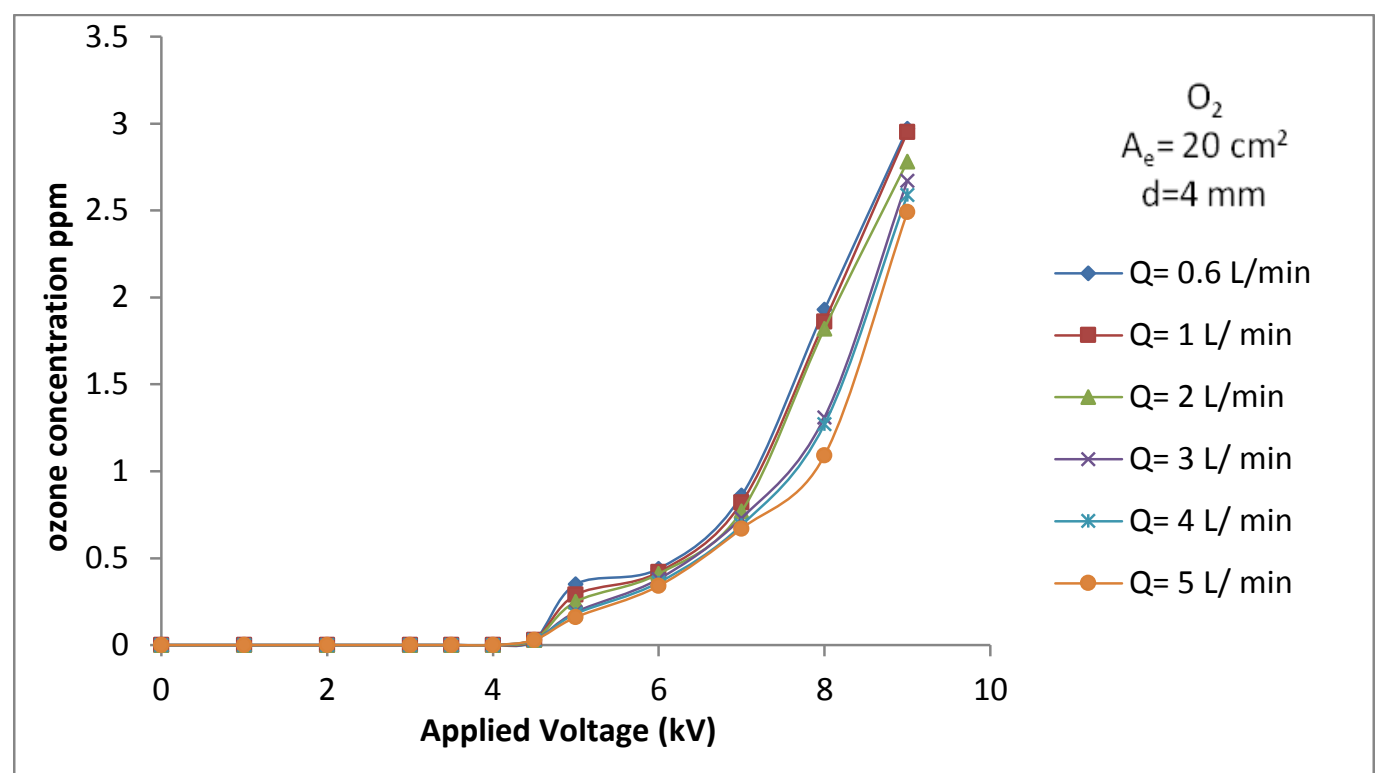

Fig.(3) Ozone concentration as a function of applied voltage at different flow rates.

It found that the Ozone was not produced at less given applied voltage $(4.5 \mathrm{kV})$ whatever the others variable. It means that our Ozone generator did not produce Ozone when the applied voltage less than $(4.5 \mathrm{kV})$. When the applied voltage increase the Ozone will began formed and its concentration increase rapidly with applied voltage for all values of the flow rate $(\mathrm{Q})$. Also we show that for a given value of applied voltage the concentration of Ozone decrease with increasing of the flow rate as shown in Fig.(3).

To study the effect of the electrode area on the Ozone concentration the cathode area had been change from $\left(20 \mathrm{~cm}^{2}\right.$ to $\left.36 \mathrm{~cm}^{2}\right)$. The Ozone concentration was measured for different value of flow rate from $(0.6,1,2,3$, 4, 5) lit/min. 


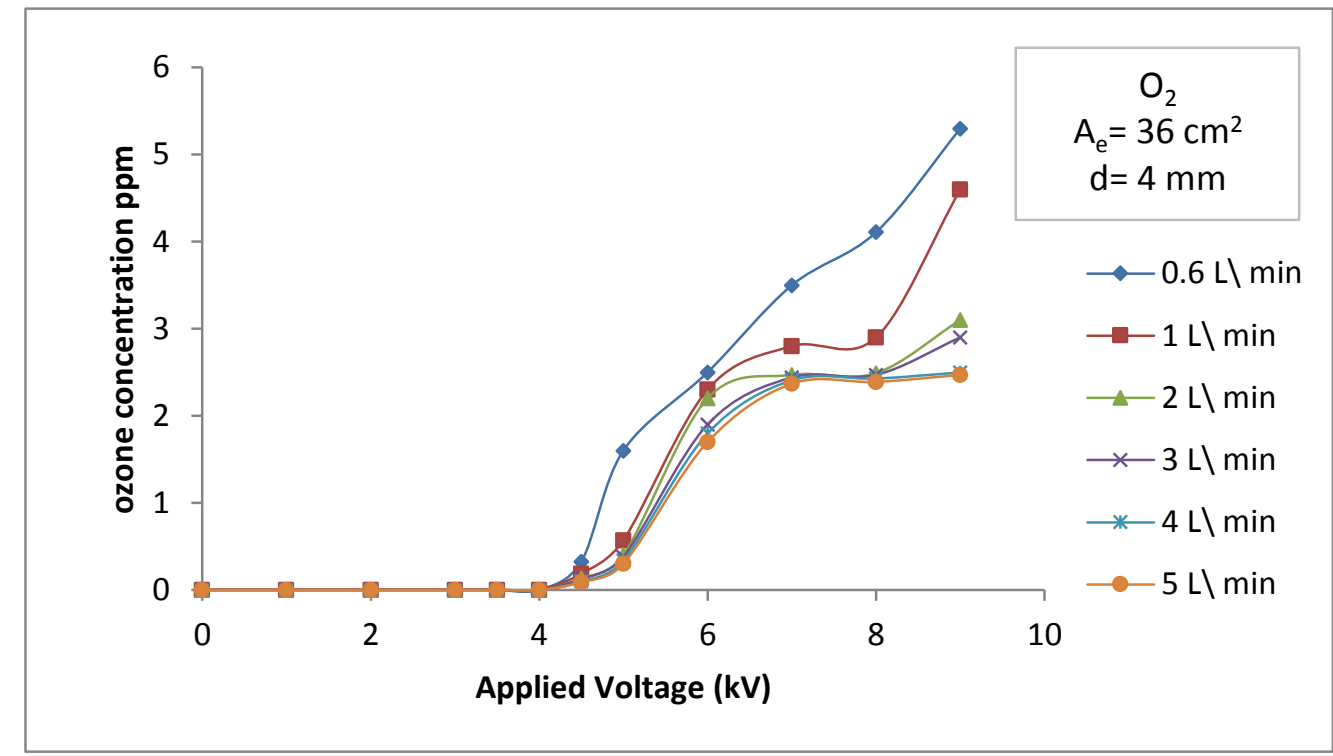

Fig.(4) Ozone concentration as a function of applied voltage at different flow rates.

We found that for a given gap space $(\mathrm{d}=4 \mathrm{~mm})$ and given applied voltage $(8 \mathrm{kV})$ When the electrode area increase from $\left(20 \mathrm{~cm}^{2}\right.$ to $36 \mathrm{~cm}^{2}$ ) the concentration of Ozone increase from (2.5 ppm to about $4.5 \mathrm{ppm})$ for the flow rate $(0.6 \mathrm{lit} / \mathrm{min})$.

This means that the electrode area is one of the most important variable in concentration of
Ozone generator. The electrode area most be large as possible to get higher Ozone concentration.

To study the effect of the gap space on the Ozone concentration the gap space had been reduced from ( $4 \mathrm{~mm}$ to $2 \mathrm{~mm}$ ) and electrode area was fixed at $\left(\mathrm{A}_{\mathrm{e}}=36 \mathrm{~cm}^{2}\right)$.

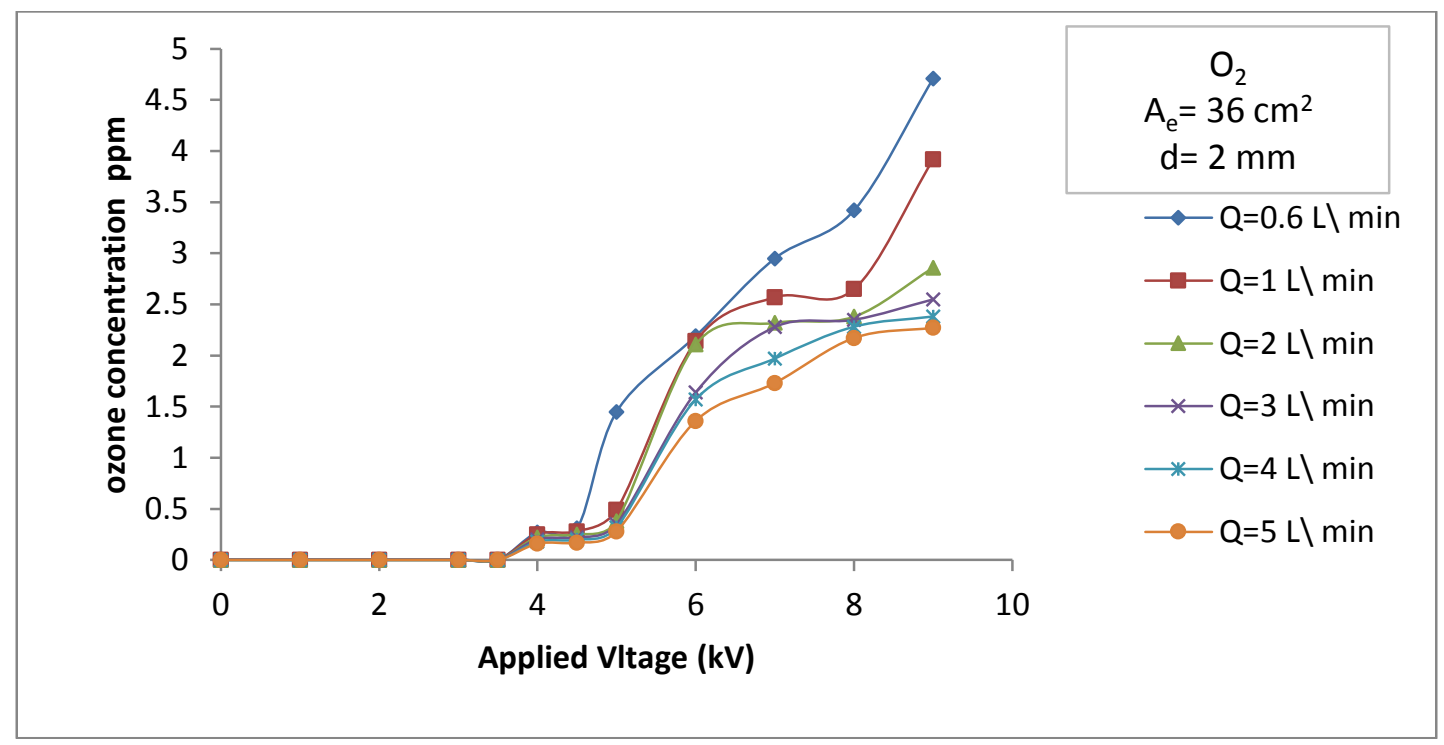

Fig.(5) Ozone concentration as a function of applied voltage at different flow rates.

The results of the Ozone concentration as a function of the applied voltage for different flow rate $(0.6,1,2,3,4,5) \mathrm{lit} / \mathrm{min}$ are plotted in Fig.(5).
By comparing Fig.(1-4) and Fig.(1-5) we can notice that in general the concentration of Ozone will increase with increasing the gap space. 
Effect of applied voltage on Ozone concentration

To study the effect of the applied voltage on the concentration of the Ozone produced by Ozone generator.
The concentration of Ozone was measured with flow rate for different applied voltage $(4.5,5,6,7,8,9) \mathrm{kV}$, and given electrode area $\left(A_{e}=20 \mathrm{~cm}^{2}\right)$, and gap space $(d=4 \mathrm{~mm})$. The results are shown in Fig.(6).

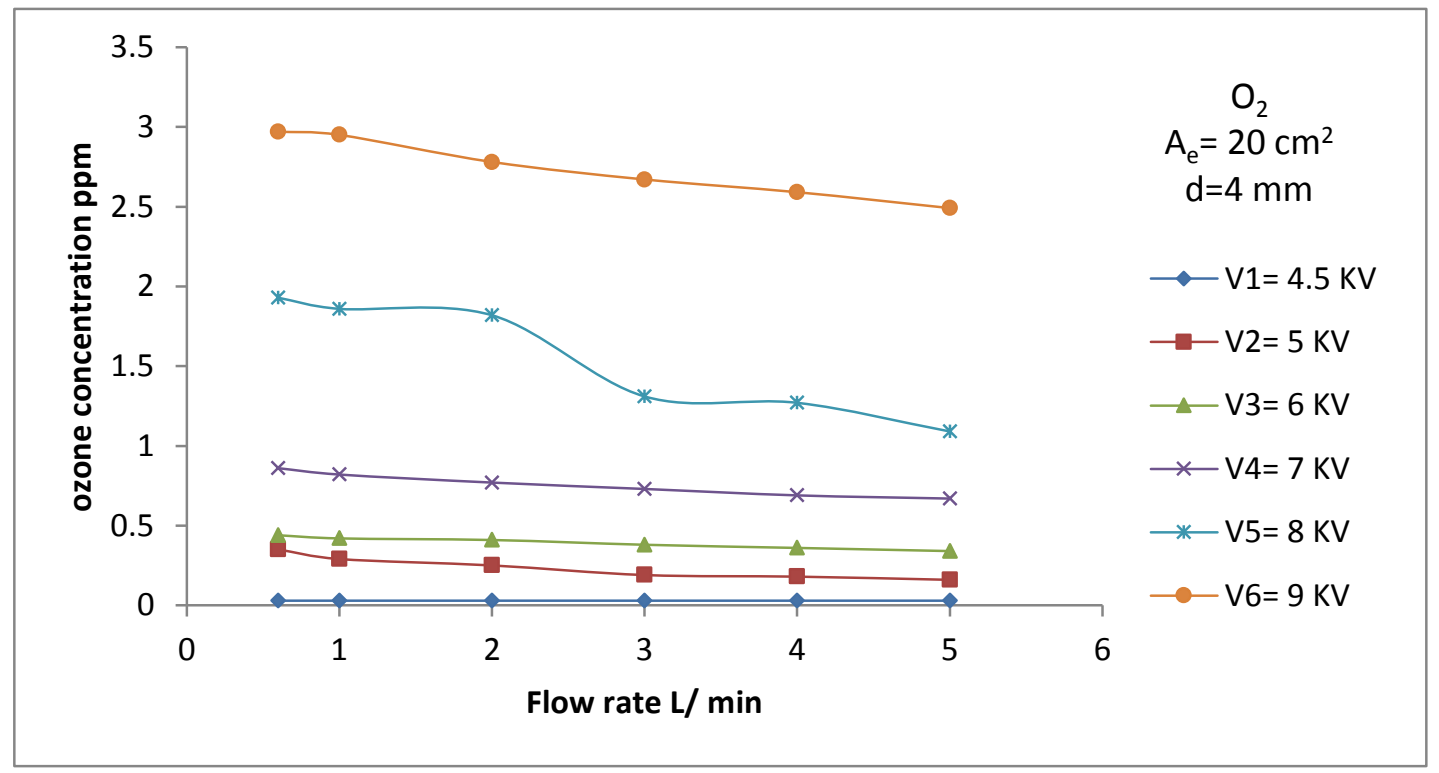

Fig.(6) Ozone concentration as a function of gas flow rate.

It can be shown that for a given flow rate the concentration of the Ozone increases with increasing applied voltage. This is because higher voltage means that higher energy given to the molecules of the gas and hence higher rate of ionization and higher concentration of Ozone.

Fig.(7) shows the Ozone concentration as a function of flow rate for different applied voltage (1-5) $\mathrm{kV}$, and electrode area $\left(\mathrm{A}_{\mathrm{e}}=36 \mathrm{~cm}^{2}\right)$, and gap space $(\mathrm{d}=2 \mathrm{~mm})$.

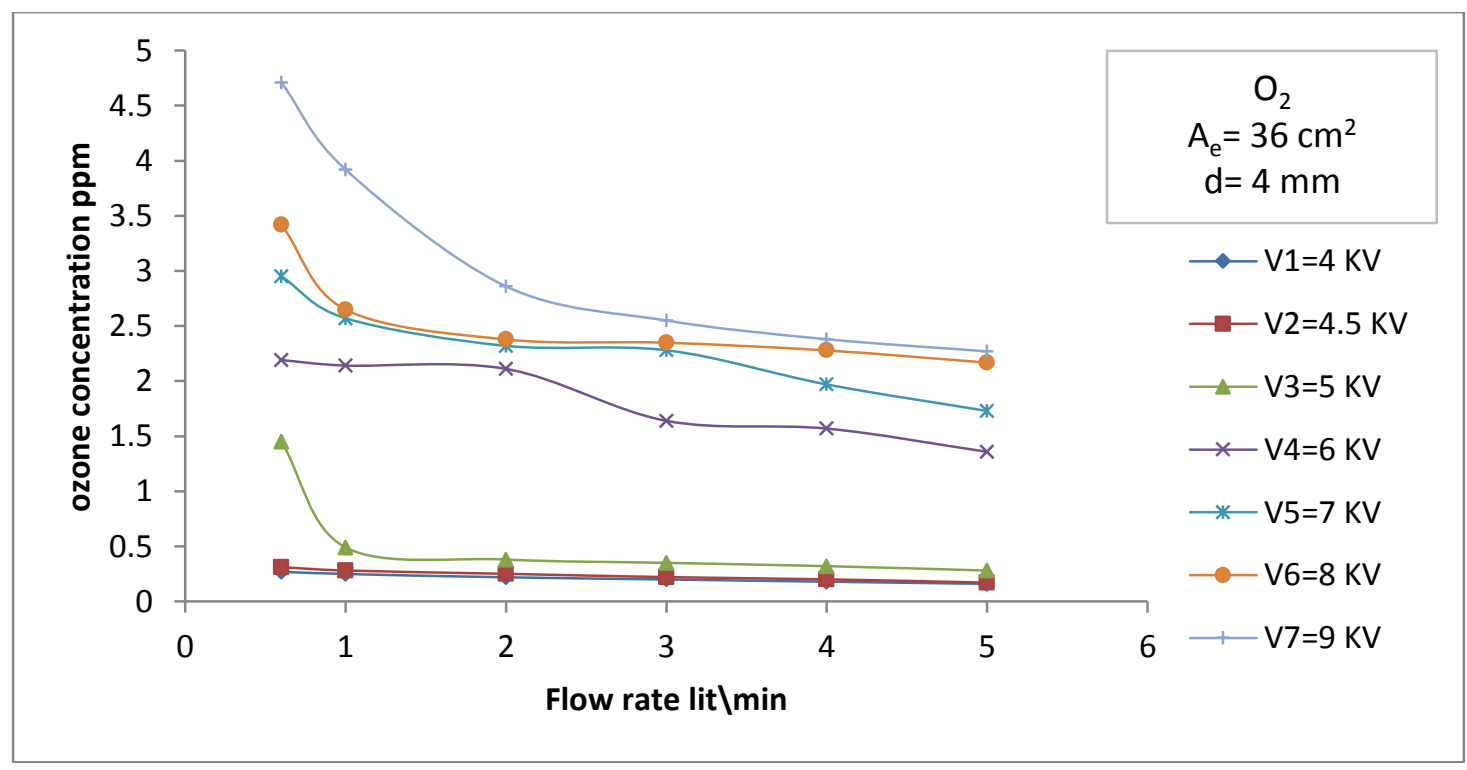

Fig.(7) Ozone concentration as a function of gas flow rate for a different applied voltage. 
Fig.(8) shows the Ozone concentration as a function of applied voltage $(0,1,2, ., 5) \mathrm{kV}$ and different electrode area $\left(\mathrm{A}_{\mathrm{e}}=20 \mathrm{~cm}^{2}\right.$, and $\left.36 \mathrm{~cm}^{2}\right)$, but gap space $(\mathrm{d}=4 \mathrm{~mm})$.

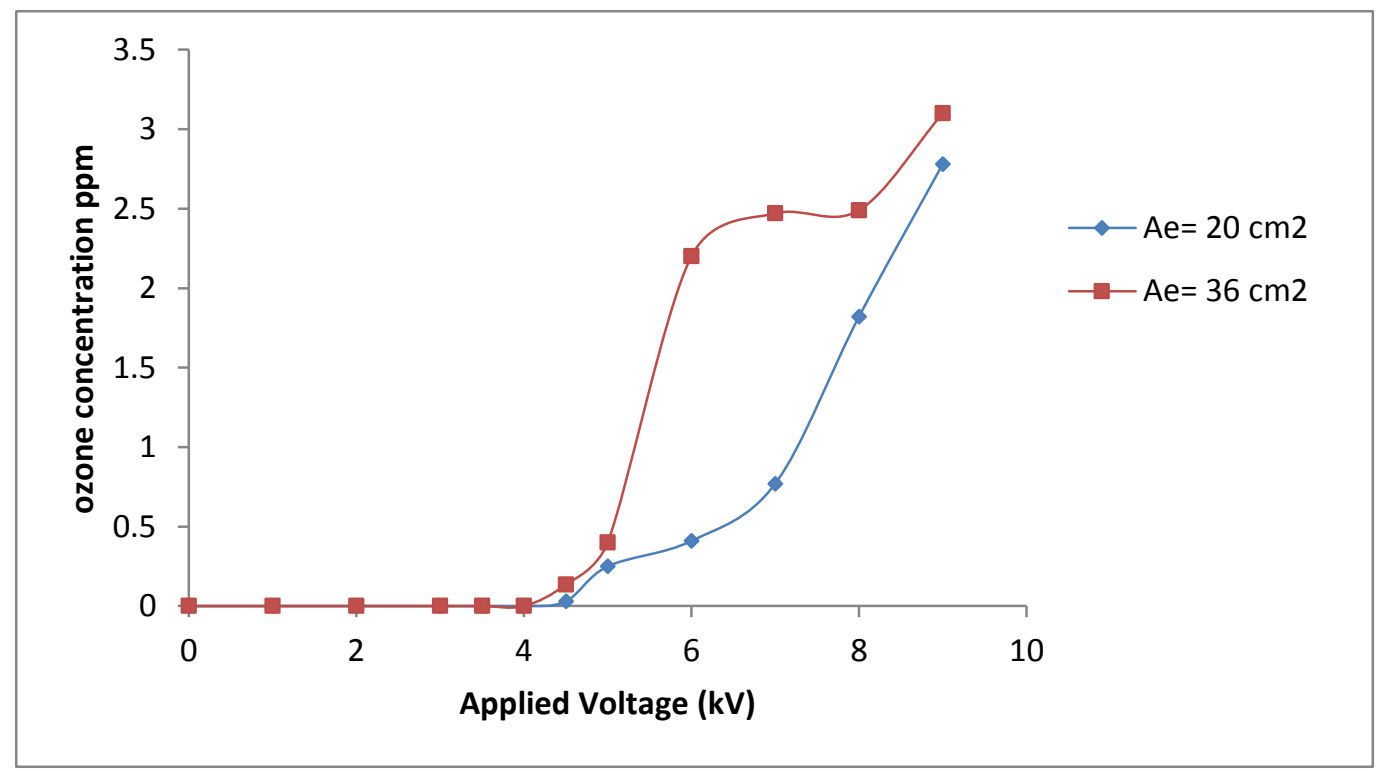

Fig. (8) Ozone concentration as a function of applied voltage at different electrode areas.

By comparing Figs. (7) and (8), one can conclude that the concentration of Ozone is increased with increasing the gap space (from $\mathrm{d}=2 \mathrm{~mm}$ to $4 \mathrm{~mm}$ ). This could be shown in Fig.(9). As a conclusion, in practical application in design Ozone generator to get higher concentration of Ozone from it must choose higher applied voltage and higher electrode area and gap space.

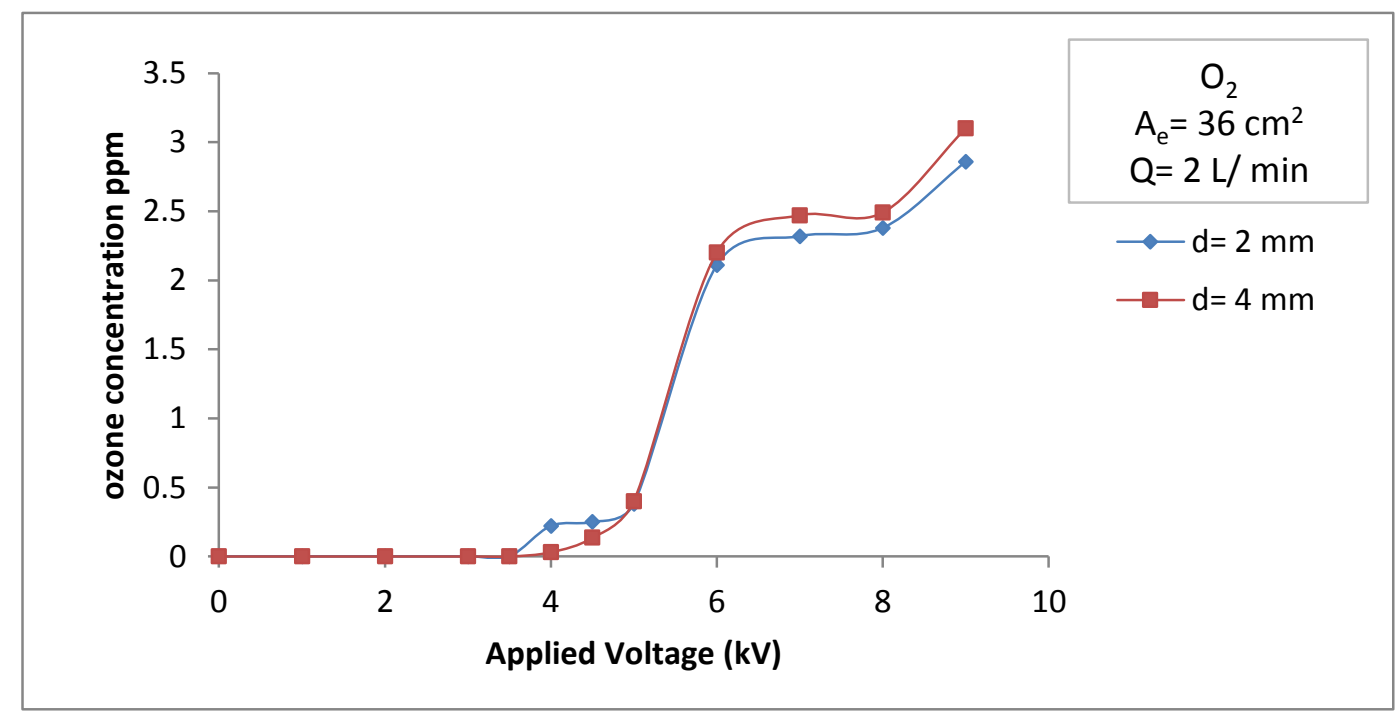

Fig.(9) Ozone concentration as a function of applied voltage for two values of gap space ( $d=2$ and $4 \mathrm{~mm})$.

\section{Conclusions}

The concentration of Ozone produced increases with increasing applied voltage,gap space between the electrodes and the electrodes area. But this concentration decreases with increasing the gas flow rate.

\section{References}

[1]Patil, S.; Bourke, P.; Frias, J.M.; Tiwari, B.K.; and Cullen, P.J.; "Inactivation of Escherichia coli in orange juice using ozone"; Journal of Food Science and 
Emerging Technologies, No.10; pp 551557; 2009.

[2] Bogaerts, A.; "Gas Discharge Plasmas and their Applications"; SpectrochimicaActa Part B, Vol. 57; pp 609-658; 2001.

[3] Chen, J.; Davidson, J.H.; "Electron Density and Energy Distributions in the Positive DC Corona: Interpretation for CoronaEnhanced Chemical Reactions"; Plasma Chemistry and Plasma Processing, Vol. 22; pp 199-224; 2002.

[4] Spyrout, N.; "New Result on a Point-toPlane DC Plasma Reactor in Low-Pressure Dried Air"; Phys. D: Appl. Phys., Vol. 27; pp 2329-2339; 1994.

[5] DEL, "Ozone Water Purification Systems, DEL Industries"; United States of America, 2002.

[6] Byoung, Ho.; Lee, Won, C.; Song, Biswaranjan, M.; and Jong, K.; "Dissolved ozone flotation (DOF) a promising technology in municipal wastewater treatment"; Desalination, Vol. 225, Issues 1-3; pp 260-273; 2008.

[7] Javier, R.; Olga, G.; and Fernando, B.; "Wastewater recycling: Application of ozone based treatments to secondary effluents"; Chemosphere, Vol. 74; Issue 6; pp 854-859; 2009.

[8] Tsugura, H.; Watanabe, T.; Shimazaki, H.; and Sameshima, S.; "Development of a monitor to simultaneously measure dissolved ozone and organic matter in ozonated water"; Water Science and Technology Vol. 37; Issue 12; pp 285-292; 1998.

[9] Viera, M. R.; Guiamet, P. S.; de Mele, M. F. L. and Videla, H. A.; "Use of dissolved ozone for controlling planktonic and sessile bacteria in industrial cooling systems"; International Biodeterioration \& Biodegradation ,Vol. 44; Issue 4; pp 201207; 1999.

[10] Clellan, Mc.; "The Silent Discharge Plasma Technology Nonequilibrium Nonthermal Plasma to Oxidize Organic Contaminants"; ENV America Incorporation, United States of America, 2003.

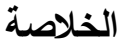

تم تصميم وتشغيل منظومه لانتاج الاوزون طبقاً لتقنية تفريغ حاجز العزل الكهربائي بأستخدام الاوكسجين كغاز ادخال لتوليد الاوزون، درس تأثنير معدل الجريان على تركيز

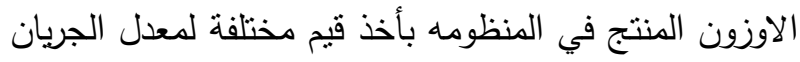

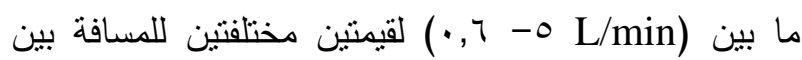
الاقطاب (d=2,4 mm)، وكذللك لقطبين مختلفين في

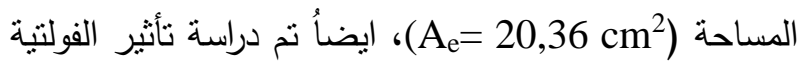
المسلطة على تركيز الاوزون وذلك بأخذ فولتيات مختلفة

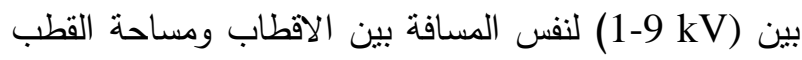
ولوحظ ان تركيز الاوزون المنتج يزداد بزيادة الفولتية المسلطة

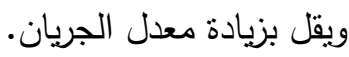

